\title{
Voices That Shape Investment Treaties: Inside, Outside and Among States
}

\author{
Chrysoula Mavromati and Sarah Spottiswood
}

\section{Contents}

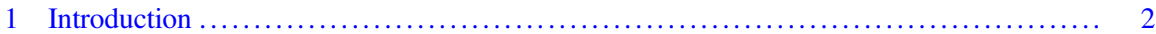

2 Three Categories of Voices That Influence Investment Treaties $\ldots \ldots \ldots \ldots \ldots \ldots \ldots \ldots \ldots, 2$

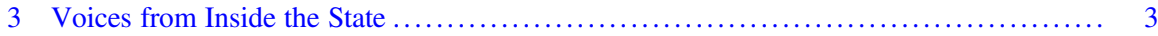

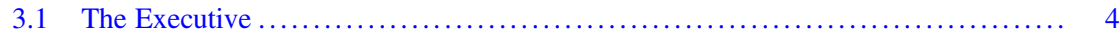

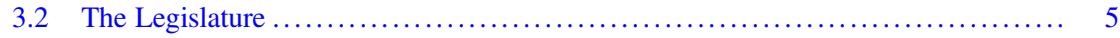

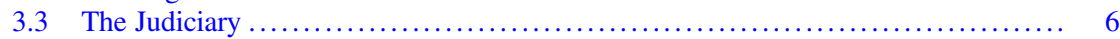

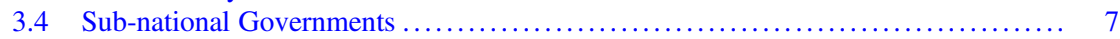

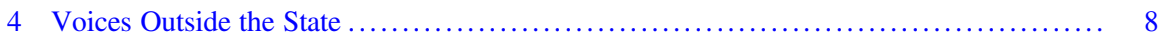

4.1 Business, Civil Society, Legal Community and Others ...................... 8

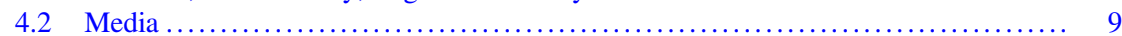

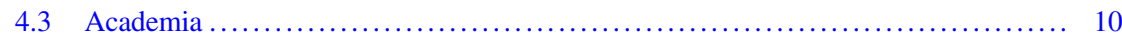

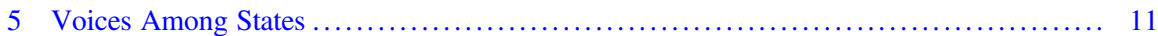

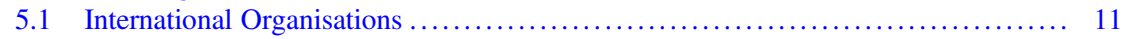

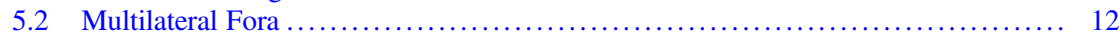

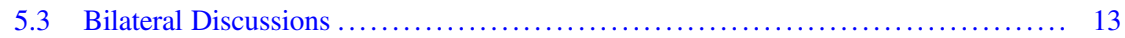

5.4 Arbitral Awards and International Judgments ........................... 13

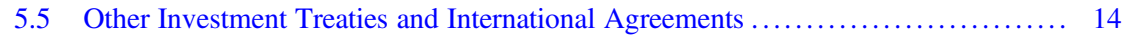

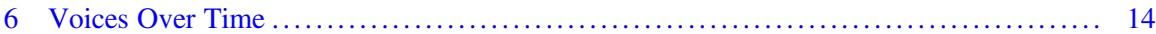

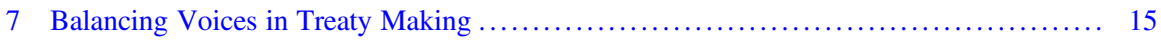

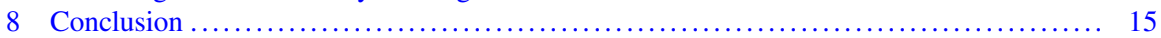

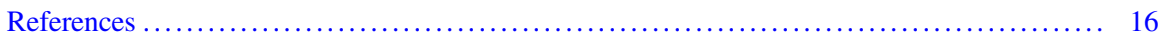

The views expressed in this chapter are those of the authors. They do not purport to reflect the opinions or views of the Government of the United Kingdom or the European Commission. The authors wish to thank Victoria Donaldson and Carlo Pettinato for their valuable comments. They would also like to thank the organisers and participants of the Colloquium on "Actors in International Investment Law: Beyond Claimants, Respondents and Arbitrator" at University Paris II Panthéon-Assas on 26 and 27 September 2019 for stimulating helpful discussions.

C. Mavromati $(\bowtie)$

European Commission, Brussels, Belgium

S. Spottiswood

Government Legal Department, London, UK

(C) The Author(s) 2021

C. Titi (ed.), Public Actors in International Investment Law, European Yearbook of

International Economic Law, https://doi.org/10.1007/978-3-030-58916-5_1 


\begin{abstract}
Investment arbitration awards often give the impression that investment treaties are designed to reflect the interests of two actors: "investors" and "states". There are in fact a myriad of actors, or "voices", behind each word in an investment agreement. This chapter identifies three broad categories of voices: voices inside, outside and among states. It explores the range of voices that influence investment treaty text by reference to those three categories. The chapter argues that modern investment treaties are multifaceted texts that are influenced by a range of voices from within and outside of government.
\end{abstract}

\title{
1 Introduction
}

Investment arbitration awards often give the impression that investment treaties are designed to reflect the interests of two actors: "investors" and "states". There are in fact a myriad of actors, or "voices", behind each word in an investment agreement. This chapter identifies three broad categories of voices that influence investment treaty text and explores the range of voices within those categories that lead to the final treaty text. It argues that modern investment treaties are multifaceted texts that are influenced by a range of voices from within and outside of states.

To begin with, this chapter identifies three categories of voices as a tool to categorise the range of voices that feed into investment treaty making. It explores the rationale for identifying these categories and possible limitations of this categorisation. Against this background, it analyses the first category of voices that influence investment treaty text: voices from inside the state. The chapter then goes on to consider the second category of voices that shape investment treaties: voices originating outside the state. It then turns to the third category of voices: voices among states. It also touches on the role of voices as expressed in past treaties. The chapter concludes with some preliminary remarks on complexities arising from balancing and prioritising of different voices in the negotiation of an investment treaty and identifies areas for further research.

\section{Three Categories of Voices That Influence Investment Treaties}

Three broad categories of voices that influence investment treaties can be identified: voices inside, outside and among states. The first category, "voices inside the state" refers to the various actors within the different branches and levels of a government. Second, "voices outside the state" includes non-state actors such as businesses, civil society and academics. Third, "voices among states" refers to multilateral and bilateral interactions among states and the role of international institutions in 
investment treaty making. The chapter draws on case studies from different countries and different negotiation processes that led to, or failed to lead to, existing treaties to show how voices in each of these categories influence the negotiation of investment treaties. The examples used are ascertained from publicly available sources.

The three categories of voices that influence investment treaties are not a perfect categorisation. They are a helpful lens through which to view the range of voices that are reflected in modern investment treaties. Some actors may not comfortably fit entirely within any one category, and some may fit into more than one. The aim of this categorisation is simply to draw attention to the diversity of voices that are amalgamated into investment treaty text and show that voices within each category influence the process in different ways.

It is also important to note that within each category and even within each kind of "voice" that is identified there is unlikely to be one homogenous viewpoint. This applies to ministers, officials and judges inside the state as much as it does to businesses, civil society or even international institutions. It may be argued that the pluralist nature of voices that influence investment treaties undermines the usefulness of a study that seeks to provide an overview of the range of voices that influence investment treaty making. However, there is a large benefit in identifying, explaining and categorising the multitude of voices both for promoting a greater understanding of the treaty-making process and as a starting point for further research into the role of different voices in more detail. This chapter seeks to address the current absence of research that outlines, on a detailed actor-by-actor basis, how different voices influence the development of model treaty text and the negotiation of investment treaties.

\section{Voices from Inside the State}

It is well-known that investment arbitration awards have involved challenges to actions by different branches of government: the legislature, ${ }^{1}$ the executive ${ }^{2}$ and the judiciary. ${ }^{3}$ Each branch of government also influences what wording appears in an investment treaty. This part explains how actors within the different branches of government, and in different levels of government, contribute to the contents of investment treaties.

\footnotetext{
${ }^{1}$ See, e.g., Philip Morris Brand Sàrl (Switzerland), Philip Morris Products S.A. (Switzerland) and Abal Hermanos S.A. (Uruguay) v. Uruguay, ICSID Case No. ARB/10/7, Award, 8 July 2016.

${ }^{2}$ See, e.g., Técnicas Medioambientales Tecmed, S.A. v. United Mexican States, ICSID Case No. ARB (AF)/00/2, Award, 29 May 2003.

${ }^{3}$ See, e.g., Eli Lilly and Company v. Canada, ICSID Case No. UNCT/14/2, Final Award, 16 March 2017.
} 


\subsection{The Executive}

It is well known that investment treaties, like all treaties, are largely negotiated by officials working in ministries in the executive branch of government, with the direction and agreement of ministers. Treaty negotiation often occurs over a number of "rounds" interspersed by periods that officials spend in capitals developing policy and seeking instructions on the approach to take in the next negotiating round.

The process often formally starts with the creation, and sometimes also the publication, of a negotiating mandate by both sides, although informal meetings between ministers and officials from each party may precede this. The mandate will be developed in ministries and agreed by ministers across government.

Policy officials, economists and lawyers within ministries first inform themselves by consulting the myriad of voices from outside the State and among States discussed below. This process involves collecting, analysing, considering, discussing, presenting, refining and clarifying the range of policy and legal options available. The result of this process is fed into national positions that are expressed in the negotiating mandate and refined throughout negotiations by officials inside and outside of the negotiating room.

Different ministers and ministries may have competing policy positions that need to be reconciled. Investment treaties may raise issues that touch on the policy priorities of numerous departments including, for example, those with responsibility for the treasury, foreign relations, trade, environment, energy, business, agriculture, tax, health and different levels of government. Governments ordinarily have a process in place for making decisions which affect many policy areas and for resolving competing policy positions. For instance, the decision making within the UK Government is often based on the "collective agreement process", also known as "write-round", which allows ministers with responsibility for different departments to express their views frankly in discussion and reach agreement on policy proposals. 4

Negotiators may need to make reactive decisions or turn to fallback positions during discussions with their counterparts. Moreover, there may be situations where officials from either negotiating party cannot resolve an issue after many rounds of negotiations, despite engaging in discussions about the range of policy and legal options available. Difficult issues that are unable to be resolved at official level are elevated to discussions between ministers and their counterparts in other governments.

\footnotetext{
${ }^{4}$ See Cabinet Office, Collective Government Agreement Process Guidance, March 2013, https:// civilservicelearning.civilservice.gov.uk/sites/default/files/cabinet_office_collective_agreement_pro cess_guidance_0.pdf.
} 


\subsection{The Legislature}

The legislature in many countries may shape the standards that are negotiated by officials in the executive branch. ${ }^{5}$ Depending on the state's constitutional arrangements, the legislature may exert influence either before negotiations begin or once a signed version of the treaty is taken to the legislature as part of ratification procedures.

The most obvious way that the legislature may shape investment treaties is by passing legislation to set out negotiating directives and, more broadly, prescribe the limits of the negotiating mandate. US negotiators, for example, are guided by negotiation objectives on foreign investment set out in the Bipartisan Congressional Trade Priorities and Accountability Act $2015 .{ }^{6}$ If the negotiating objectives set out in that legislation are advanced in a trade agreement and other requirements in the legislation are met, the agreements are likely to benefit from advantageous congressional procedures at the ratification stage, including a prohibition on amendments to the legislation implementing the agreement. The US Congress decides whether the requirements of the legislation are met so that the ratification process for a particular trade agreement may be expedited. ${ }^{7}$

Parliamentary committees, such as Australia's Joint and Senate Standing Committees on Foreign Affairs, Defence and Trade and on Treaties, may conduct inquiries before or during negotiations ${ }^{8}$ or once a treaty has been signed. ${ }^{9}$ Committees inform themselves with written and oral evidence provided by witnesses who may be from businesses, academia or civil society. Members of parliamentary committees, and the research staff who assist them, then prepare reports that make recommendations to the government. These reports are in turn considered by the government and interested civil society organisations and business who may refer to the reports to bolster their positions.

Depending on the ratification process in each country, legislatures may be able to shape investment treaties by refusing to ratify agreements due to concerns with specific content, or to amend the negotiating mandate in the course of the negotiations. This may force the executive back to the negotiating table. For instance, the non-ratification of bilateral investment treaties (BITs) by Brazil has also been, in

\footnotetext{
${ }^{5}$ There is extensive academic debate about the role of Parliament in treaty making. See, e.g., Schütze (2017), p. 7.

${ }^{6} 19$ USC $\S 3802$.

${ }^{7}$ See Congressional Research Service, Trade Promotion Authority (TPA): Frequently Asked Questions, 21 June 2019, https://crsreports.congress.gov/product/pdf/R/R43491.

${ }^{8}$ See, e.g., Joint Standing Committee on Foreign Affairs, Defence and Trade, Australia's trade and investment relationship with Japan and the Republic of Korea, 3 June 2013, https://www.aph.gov. au/Parliamentary_Business/Committees/House_of_Representatives_Committees?url=jfadt/ japanandkoreatrade/report.htm.

${ }^{9}$ See, e.g., Senate Standing Committee on Foreign Affairs, Defence and Trade, Proposed TransPacific Partnership (TPP) Agreement, 7 February 2017, https://www.aph.gov.au/Parliamentary Business/Committees/Senate/Foreign_Affairs_Defence_and_Trade/TPP/Report.
} 
part, attributed to resistance by the National Congress of Brazil. ${ }^{10}$ Another example is when the European Parliament passed a resolution requesting the European Commission "to replace investor-state arbitration with a new system for resolving disputes between investors and states" in the Transatlantic Trade and Investment Partnership (TTIP). ${ }^{11}$ This bolstered the European Commission's decision to pursue the Investment Court System in its future negotiations, including to renegotiate the relevant provisions of the Comprehensive Economic and Trade Agreement (CETA) which initially contained a traditional investor-state arbitration mechanism. $^{12}$

The voices of individual members of parliament may also influence the policy positions taken by ministers. Opposition ministers and members of parliament may meet with ministers privately or ask them questions in parliament. In this way, voices from outside states that have lobbied members of parliament can inform and be funnelled into a voice inside the state to influence investment treaties.

\subsection{The Judiciary}

Courts supervise investment arbitration proceedings and preside over enforcement and execution of arbitral awards, but they also influence the existence and content of investment provisions. For example, Colombia's Constitutional Court has recently ruled that certain provisions of the BIT between Colombia and France were "conditionally constitutional" ("condicionalmente exequible") subject to a joint interpretative note being issued to clarify the meaning of certain standards of treatment. ${ }^{13}$

Opinion 1/17 of the Court of Justice the European Union (CJEU) provides another illustration of how the judiciary may shape the content of investment treaties. ${ }^{14}$ In that case, the CJEU was asked whether the Investment Court System in CETA was compatible with EU law and the Court found that it was. This case shows two ways in which courts influence investment treaties. First, the arguments put by the European Commission and some member states show how EU treaty negotiators sought to include "safeguards" in the investment chapter of CETA that

\footnotetext{
${ }^{10}$ Titi (2016) and Campello and Lemos (2015).

${ }^{11}$ European Parliament resolution of 8 July 2015 containing the European Parliament's recommendations to the European Commission on the negotiations for the Transatlantic Trade and Investment Partnership (TTIP) (2014/2228(INI)).

${ }^{12}$ Puccio and Harte (2017).

${ }^{13}$ Sentencia C-252, Control de constitucionalidad del Acuerdo entre el Gobierno de la República de Colombia y el Gobierno de la República Francesa sobre el Fomento y Protección Recíprocos de Inversiones, suscrito en la ciudad de Bogotá, el 10 de julio de 2014, y de la Ley 1840 de 12 de julio de 2017, por medio de la cual se aprobó este tratado internacional, http://www.corteconstitucional. gov.co/relatoria/2019/c-252-19.htm\#_ftn233 cited in Prieto (2019).

${ }^{14}$ Opinion 1/17 of 30 April 2019, ECLI:EU:C:2019:341.
} 
respected previous jurisprudence on setting up international courts by the EU. ${ }^{15}$ Second, the opinion could also be read as setting minimum standards for investorstate dispute settlement provisions in EU agreements. ${ }^{16}$

Another example of influence by courts on investment treaties can be seen in the expression of investment protections in US investment treaties, which often closely mirror equivalent standards set in domestic law by US courts. For instance, the factors set out in Annex B of the US Model BIT of 2012 for the determination of whether an action or series of actions by a party has an effect equivalent to direct expropriation, that is, formal transfer of title or outright seizure, are drawn from US Supreme Court jurisprudence on compensable takings under the Fifth Amendment to the US Constitution. ${ }^{17}$ In this way, US judicial decisions have indirectly influenced or inspired the standards negotiated by the executive branch of the US government.

\subsection{Sub-national Governments}

The influence of sub-national governments on the text of investment treaties may also be important. Sub-national governments may be seen as a "microcosm" containing, at a regional level, all the voices discussed in this chapter that influence treaties from inside and outside the state. In most countries, it is the national government that has constitutional power for treaty making which may affect the influence of voices from sub-national governments in investment treaties. The degree of influence and involvement of sub-national governments in the negotiations of an agreement may vary depending on the constitutional division of competences between the central, regional and local governments. For example, Canadian provinces played a major role and were invited into the negotiation room in CETA negotiations due to the comprehensive nature of the agreement which covered aspects, such as government procurement and agriculture, which fell within the competence of the provinces. ${ }^{18}$ Even in those countries where central governments have exclusive power for treaty making on all subject matters, for example in India and Australia, ${ }^{19}$ coordination may still occur between the central government and regional or local governments, even if this may not be constitutionally required. For example, Australian states and territories were consulted before, during and after the negotiation of the Australia-United States Free Trade Agreement even though it is

\footnotetext{
${ }^{15}$ Opinion 1/17 of 30 April 2019, ECLI:EU:C:2019:341, [70]-[78].

${ }^{16}$ Bungenberg and Titi (2019).

${ }^{17}$ Penn Central Transportation Co v New York City, 438 US 104 (1978). See Caplan and Sharpe (2013), p. 755, 790.

${ }^{18}$ Paquin (2013).

${ }^{19}$ See Article 253 of the Constitution of India. See also, in relation to Australia, section 51(xxix) of the Constitution of Australia.
} 
the central government that has exclusive constitutional power to negotiate treaties. $^{20}$

\section{Voices Outside the State}

Outside of the state, there are a wide range of voices, namely business organisations, investors, non-governmental organisations, the media, academia and the legal profession, that play their own role in informing policies and thus influencing the text of a treaty. These voices may use different channels, including contacting members of the legislature or government departments, formal public consultations, official or unofficial stakeholder engagements, interaction through social media, public campaigns, publications and other methods of influencing those inside the state.

\subsection{Business, Civil Society, Legal Community and Others}

Different stakeholder groups, such as business, civil society and the legal community in each state, may provide their views on investment treaties through the process of stakeholder engagement run by governments. ${ }^{21}$ Stakeholder engagement mechanisms act as "knowledge platforms", which are intended to ensure sustained and upto-date information on the stances of the different stakeholder groups. ${ }^{22}$ Stakeholder engagement can take various forms and may range from unofficial, ad hoc meetings to dedicated formal events. ${ }^{23}$ Exchanges may occur between relevant government departments and business associations, trade unions, academics, non-government organisations (NGOs), the legal community and others. Although stakeholder engagement is normally an ongoing activity built into everyday work of government departments, enabling an inclusive and continuous dialogue, it is often intensified when a government is in the process of reviewing existing policies and preparing new proposals.

\footnotetext{
${ }^{20}$ See Parliament of Australia, Report 61: The Australia-United States Free Trade Agreement, June 2004, https://www.aph.gov.au/ /media/wopapub/house/committee/jsct/usafta/report/fullreport_ pdf.ashx, pp. 36-42.

${ }^{21}$ See, e.g. public consultation on the US investment model agreement https://ustr.gov/about-us/ policy-offices/press-office/blog/2014/March/Stakeholder-Consultations-Investment-and-the-TTIP; public consultation on Canada's foreign investment promotion and protection agreements https:// www.international.gc.ca/trade-commerce/consultations/fipa-apie/index.aspx?lang=eng.

${ }^{22}$ British Chamber of Commerce, UK Trade Policy-Institutions and Procedures for the 21st Century https://www.britishchambers.org.uk/media/get/Trade\%20Policy\%20and\%20Stakeholder $\% 20$ Engagement $\% 20-\% 20$ full $\% 20$ report.pdf, p. 8 .

${ }^{23}$ Ibid.
} 
In this regard, public consultations are a common tool in the investment treatymaking process not least because they enable reaching out to a wide range of stakeholders. Governments use public consultations to seek views, evidence and opinions from interested parties with a view to collecting empirical information for analytical purposes, measuring expectations and identifying non-evident policy alternatives when making a policy decision. ${ }^{24}$

An illustrative example of how public consultations have shaped the content of investment agreements is in relation to the EU's approach to investor-state dispute settlement, the Investment Court System. Public consultation in 2014 on investment protection and investor-state dispute settlement (ISDS) in the proposed TTIP between the EU and the United States recorded an unprecedented mobilisation by civil society in Europe. The consultation responses raised concerns around the establishment and functioning of arbitral tribunals and the lack of appellate review of ISDS awards. The public consultation and ensuing debate, that involved the European Parliament, EU member states and civil society, led the European Commission to develop the Investment Court System as its preferred mechanism for resolving disputes between investors and states rather than ad hoc investor-state arbitration. ${ }^{25}$

Lobbying activity between interest groups and members of the legislature is also common. Feedback received from such meetings, together with input from other sources, may form part of the evidence base on which investment policies are designed and the content of model investment agreements is ultimately shaped.

\subsection{Media}

The news media can also be influential in shaping policies and, by extension, in shaping a treaty's content. It can serve both as a separate actor that carries its own views, or as a vehicle that gives floor to voices that otherwise may not have found their way to a broader audience. This is particularly the case with digital and social media which have facilitated dissemination of information and dialogue among interested parties on all possible issues, including investment policies and arbitration. For example, social media played a pivotal role in the development of the movement opposing TTIP negotiations and in the backlash against ISDS. An analysis of European online media shows that anti-TTIP groups dominated $60 \%$ of online media coverage from June to November $2014 .{ }^{26}$ ISDS by far occupied the

\footnotetext{
${ }^{24}$ Organisation for Economic Cooperation and Development, Background Document on Public Consultation https://www.oecd.org/mena/governance/36785341.pdf, p. 1 .

${ }^{25}$ See European Commission, A Multilateral Investment Court, September 2017, http://trade.ec. europa.eu/doclib/docs/2017/september/tradoc_156042.pdf.

${ }^{26}$ Bauer (2015).
} 
largest share in total online media coverage (roughly 40\%), followed by genetically modified organisms (13\%), transparency $(10 \%)$ and culture $(10 \%){ }^{27}$

Social media is used by academics, NGOs and other groups to express views on different matters, including investment policies. At the same time, in response to demands for more transparency and with a view to receiving direct feedback from the public, social media is being increasingly used by governments to communicate different actions including legislative proposals, initiatives and updates on the progress of trade and investment negotiations and thus serves as a platform for direct feedback from the public. ${ }^{28}$

\subsection{Academia}

Academia also plays a key role in shaping developments in the field of investment law and policy, and thus inevitably in informing the content of investment treaties. For instance, Roberts argues that the rise of public law and public international law paradigms in investment legal scholarship has both reflected and reinforced concerns about the lack of transparency in investment treaty arbitration, with states responding to legitimacy critiques by adopting various reforms aimed at increasing transparency. ${ }^{29}$ Broadly speaking, governments interact with academia directly and indirectly. Academics may participate directly in advisory committees of experts which are consulted by policymakers or may be commissioned to conduct evidence reviews. Academics may also be seconded to government departments to support policymaking. ${ }^{30}$

Aside from the direct involvement of academics in policymaking, the product of their independent academic work also plays an influential role in shaping investment treaties. There is indeed an increasing number of publications, including titles, journals and blogposts dedicated to international investment law, offering views and evidence from scholars and practitioners on investment law and policy matters. Quite often dedicated government departments will have access to databases that host such articles whereas, in other cases, such material may find its way to government through direct exchanges between academics and government officials.

Conferences, colloquia and workshops hosted by research institutes, universities, law firms and government departments enable government officials to engage with scholars and practitioners and bring any key take-away points back to their ministries to inform decision-making and eventually the content of an investment treaty.

\footnotetext{
${ }^{27}$ Ibid.

${ }^{28}$ For instance, the UK government and individual UK government departments maintain twitter accounts on which they publish information on their services, initiatives, actions etc.

${ }^{29}$ Roberts (2013).

${ }^{30}$ Sasse and Haddon (2018).
} 
Finally, there have also been instances of academics seeking to influence investment treaty making through different forms of activism. For example, on 31 August 2010, approximately 50 academics signed a statement strongly criticising the existing investment treaty regime. ${ }^{31}$ The statement was produced against the backdrop of several ongoing processes at the time, such as the EU's development of a common investment policy, the Trans-Pacific Partnership negotiations and regional initiatives in Latin America to reform investment law and arbitration. It called on states to review their investment treaties with a view to withdrawing from or renegotiating them and urged states to take steps to replace or curtail the use of investment treaty arbitration while strengthening their domestic justice system. ${ }^{32}$

\section{Voices Among States}

Third, voices among states play a distinct role in shaping and informing national positions, which are ultimately reflected in the content of investment treaties. These voices include international organisations, multilateral fora, bilateral discussions, the jurisprudence of international courts and tribunals and international agreements.

\subsection{International Organisations}

Policymakers and treaty negotiators heavily draw on research carried out by international organisations such as the Organisation for Economic Co-operation and Development (OECD) or the United Nations Conference on Trade and Development (UNCTAD). ${ }^{33}$ International organisations observe trends across the world and select, classify and analyse data in relation to, for example, investment policies, existing regulatory, legal and institutional frameworks, investment agreements and arbitral awards. UNCTAD's Investment Policy Hub, for instance, offers a wealth of tools and information on investment policies and investment agreements, including possible policy options which may be considered by policymakers and treaty negotiators when drawing up investment policies and model treaties. ${ }^{34}$

\footnotetext{
${ }^{31}$ Public Statement on the International Investment Regime, Aug. 31, 2010.

${ }^{32}$ Ibid.

${ }^{33}$ OECD, Investment Policy, https://www.oecd.org/investment/investment-policy/; UNCTAD, International Investment Policies for Development, https://unctad.org/en/pages/publications/IntlInvestment-Policies-for-Development-(Issue-Series).aspx.

${ }^{34}$ For further information on UNCTAD's Investment Policy Hub, see https://investmentpolicy. unctad.org/.
} 


\subsection{Multilateral Fora}

At the same time, many international organisations host regular fora which bring together government representatives from around the world to exchange information and experiences on investment law and policies with a view to developing good practices. These allow treaty negotiators to remain up to date on different trends, discuss concerns and explore points of convergence or divergence with other countries, which can further facilitate discussions on a bilateral level when negotiating an investment treaty. One such forum is the OECD Freedom of Investment Roundtables which bring together governments from around the world to discuss investment issues. ${ }^{35}$

Aside from the existing institutionalised fora, a great deal of work is carried out by ad hoc intergovernmental working groups which are set up to address specific issues. These working groups may develop rules which may then be adopted or incorporated into investment treaties. A recent example of an intergovernmental forum that delivered successfully on its mandate in the investment field is the United Nations Commission on International Trade Law (UNCITRAL) Working Group II which produced the UNCITRAL Rules on Transparency in Treaty-based InvestorState Arbitration and the United Nations Convention on Transparency in Treatybased Investor-State Arbitration. ${ }^{36}$ There are also a number of working groups that are currently shaping developments in the investment treaty field, including UNCITRAL Working Group III on the reform of investor-state dispute settlement and the ICSID Rules Amendments State Consultations. ${ }^{37}$ The discussions that are being held in these working groups are informative for treaty negotiators as they bring together an unprecedented number of governments which are jointly trying to address shared concerns around the future of investor-state dispute settlement drawing on their investment treaty experience. Discussions in these working groups are supported by extensive academic work and empirical research by the UNCITRAL and ICSID Secretariats but also by other participants, including academics, practitioners and civil society organisations. Other than assisting with the specific discussions around multilateral reform, these contributions serve as a source of information and evidence for governments when reviewing their investment policies and model investment agreements.

\footnotetext{
${ }^{35}$ For further information on the OECD Freedom of Investment Roundtables, see https://www.oecd. org/daf/inv/investment-policy/foi.htm.

${ }^{36}$ See United Nations Convention on Transparency in Treaty-based Investor State Arbitration, https://uncitral.un.org/en/texts/arbitration/conventions/transparency.

${ }^{37}$ UNCITRAL Working Group III: Investor-State Dispute Settlement Reform, https://uncitral.un. org/en/working_groups/3/investor-state; ICSID Rules and Regulations Amendment Process, https://icsid.worldbank.org/en/amendments.
} 


\subsection{Bilateral Discussions}

Additionally, government officials regularly meet in the margins of international meetings, and also during dedicated bilateral meetings between governments (for example, at ministerial or diplomatic visits), which provide an opportunity for policy ideas and textual solutions to be developed between states. These meetings may be ad hoc or in the context of special bilateral working groups set up to facilitate discussions and negotiations between countries.

\subsection{Arbitral Awards and International Judgments}

Arbitral awards are arguably among the "loudest" voices in the treaty-making process. Depending on the approach taken, arbitral awards could be considered to fall either into the category of "voices among states" or "voices outside the state". If arbitral awards are viewed as a product of tribunals that are set up by states to perform an adjudicatory function, they can be seen to fall within the realm of "voices among states". However, if emphasis is placed on the fact that arbitral awards are issued by an independent tribunal outside the state, then it may be more intuitive to classify them as "voices outside the state". As noted earlier, the categorisation of voices in this chapter primarily serves presentational purposes.

Arbitral awards encompass tribunals' interpretation of treaty provisions, which enables treaty negotiators to test the boundaries of treaty language, identify any gaps or imperfections in existing treaties and fix those in future treaties. One recent example can be seen in additions of carve-outs for tobacco control measures in various investment chapters following the investment treaty disputes brought by tobacco companies against Australia and Uruguay. ${ }^{38}$

However, it is not just arbitral awards that may influence the words and content of a treaty; the decisions of international courts could be highly influential too. The jurisprudence of the International Court of Justice (ICJ), the World Trade Organisation (WTO) and other international courts and tribunals may be drawn on by investment treaty negotiators as a comparative device. One can discern, for instance, the influence of the ICJ's Barcelona Traction judgment ${ }^{39}$ in the inclusion of indirect investments, most notably in the form of shareholdings, in investment treaties, as a

\footnotetext{
${ }^{38}$ See, e.g., Article 29.5 of the Comprehensive and Progressive Transpacific Partnership and Article 22 of the Singapore - Australia Free Trade Agreement. These provisions were added following Philip Morris Asia Limited v. Australia, PCA Case No. 2012-12, Award on Jurisdiction and Admissibility, 17 December 2015 and Philip Morris Brands Sàrl, Philip Morris Products SA and Abal Hermanos SA. v. Uruguay, ICSID Case No. ARB/10/7, Award, 8 July 2016.

${ }^{39}$ Barcelona Traction, Light and Power Company Limited (New Application, 1962), Belgium v. Spain, Judgment, Merits, Second Phase, (1970) 9 ILM 227.
} 
result of the finding in that judgement about the limited standing of shareholders under customary international law. ${ }^{40}$

\subsection{Other Investment Treaties and International Agreements}

Finally, investment treaties may carry influence from investment treaties between other states which respectively reflect a myriad of other voices. This is demonstrated by the way that similar provisions can be seen in a number of different treaties between unrelated parties. It has been observed to this effect that most investment treaties were negotiated from a relatively small set of similar model BITs, which makes them "bilateral in form but somewhat multilateral in substance." 41 For example, although there may be slight differences in the definition of "investment" between treaties and over time, there are ascertainable common features that show the capacity for "cross-fertilisation" between investment agreements. ${ }^{42}$

Moreover, quite often investment treaties incorporate disciplines found in other international agreements, thus broadening considerably the scope of voices that shape the content of an investment treaty. Investment agreements, for instance, increasingly import language from the general exceptions and security exception clauses found in the WTO Agreements. ${ }^{43}$

\section{Voices Over Time}

Past investment treaties concluded by the state or model investment agreements that incorporate voices from these three categories are also heard by governments when negotiating newer treaties or in the process of developing a model investment agreement. Past treaties may often serve as a starting point, but as they reflect the prevailing political and socio-economic conditions at a particular time, some content may prove outdated or imperfect over time, particularly in light of subsequent arbitral awards, in which case their viability and contemporariness may need to be reviewed.

As with all voices that feed into the words on the page of a treaty, the weight to be given to these past voices is one question that must be considered in the treatymaking process. There is value in treaty provisions that relate to investors and crossborder commerce remaining constant where it creates certainty and predictability in

\footnotetext{
${ }^{40}$ Baumgartner (2016), pp. 261-262.

${ }^{41}$ Roberts (2013).

${ }^{42}$ See, e.g., UNCTAD, Bilateral Investment Treaties 1995-2006: Trends in Investment Rulemaking, February 2007, https://unctad.org/en/Docs/iteiia20065_en.pdf, pp. 7-10.

${ }^{43}$ Mitchell et al. (2018).
} 
business transactions and government decision making. However, the need for certainty must be weighed against the inevitable need to modernise a treaty to reflect social, legal, political or economic developments and the desire for treaties to reflect the policies of different administrations.

\section{Balancing Voices in Treaty Making}

Voices in each of the three categories (inside, outside and among states) in one state may influence its model treaty, which is a document that contains that state's preferred treaty provisions. However, treaties must have more than one party and as investment treaties represent a negotiated outcome, the influence that different voices from each state party exert on the final text varies. It may be difficult to discern from the final text how each voice that influences each state party has been reflected in the text and ultimately shaped the final outcome.

There are questions about how these voices are considered, weighed, filtered and prioritised by treaty negotiators in the process of negotiating and drafting an investment agreement. It may be that certain voices are "louder" or given priority due to the preponderance of evidence or viewpoints, ministerial or legislative preference or social or economic significance, but there is scope for further work to analyse these influences.

There are also questions around the effectiveness and legitimacy of any balancing exercise conducted by states which are ripe for further research. Balancing the range of voices feeding into the process of treaty making is a complex task, particularly where voices conflict with other voices both from one state and from different negotiating parties. Further complexities also arise in the case of large multi-party modern treaties with investment provisions, such as the Comprehensive and Progressive Trans-Pacific Partnership, where a multitude of voices must be combined and distilled into one single agreement.

\section{Conclusion}

The text of investment treaties is an amalgamation of different voices from inside, outside and among states. Legislatures, ministers, courts, officials, businesses, civil society, academics, other states, intergovernmental organisations, international tribunals and other treaties are all part of a rich tapestry of influences that treaty negotiators from each state take into the negotiating room. What emerges in the text of a treaty must necessarily weigh and distil this collection of voices heard by each party and between the parties to the treaty. By giving a comprehensive overview of the range of voices that feed into the investment treaty-making process, it is hoped that this study will shed further light on the process of investment 
treaty making whilst serving as fertile ground for further research on how these voices are balanced in the text of an investment treaty.

\section{References}

Bauer M (2015) Campaign-triggered mass collaboration in the EU's online consultations: the ISDSin-TTIP case. Eur View 14:121-129

Baumgartner J (2016) Treaty shopping in international investment law. Oxford University Press, Oxford

Bungenberg M, Titi C (2019) CETA opinion - setting conditions for the future of ISDS EJIL Talk ! 5 June 2019: https://www.ejiltalk.org/ceta-opinion-setting-conditions-for-the-future-of-isds/

Campello D, Lemos L (2015) The non-ratification of bilateral investment treaties in Brazil: a story of conflict in a land of cooperation. Rev Int Polit Econ 22(5):1055-1086

Caplan L, Sharpe J (2013) United States. In: Brown C (ed) Commentaries on selected model investment treaties. Oxford University Press, Oxford, pp 755-850

Mitchell A, Munro J, Voon T (2018) Importing WTO general exceptions into international investment agreements: proportionality, myths and risks. In: Sachs L, Johnson L, Coleman J (eds) Yearbook of international investment law and policy 2017. Oxford University Press, Oxford

Paquin S (2013) Federalism and the governance of international trade negotiations in Canada: comparing CUSFTA with CETA. Int J 68(4):545-552

Prieto P (2019) The Colombian constitutional court judgment C-252/19: A new frontier for reform in international investment law' EJIL Talk ! 29 July 2019: https://www.ejiltalk.org/thecolombian-constitutional-court-judgment-c-252-19-a-new-frontier-for-reform-in-internationalinvestment-law/

Puccio L, Harte R (2017) From arbitration to the investment court system (ICS): the evolution of CETA rules; in depth analysis prepared for the European Parliament

Roberts A (2013) Clash of paradigms: actors and analogies shaping the investment treaty regime. Am J Int Law 107(1):45-94

Sasse T, Haddon C (2018) How Government can work with Academia. Institute for Government, London

Schütze R (2017) Parliamentary democracy and international treaties. Global Policy 8(6):7-14

Titi C (2016) International investment law and the protection of foreign investment in Brazil. TDM 2(13):4

Chrysoula Mavromati is an Investment Policy Officer and Negotiator at the Directorate- General for Trade of the European Commission. Prior to this, she was Legal Adviser at the UK Department for International Trade, where she advised on investment treaty negotiations and disputes, trade law and international law issues. She was formerly Legal Counsel-Institutional Matters to the International Centre for Settlement of Investment Disputes (ICSID) at the World Bank in Washington, DC. She has also worked as a Fellow with the Operations Policy Unit of the World Bank's Legal Vice Presidency and has completed stints with the International Trade and Investment Group of Hogan Lovells in Brussels and the Legal Unit of the General Directorate for Trade of the European Commission.

Sarah Spottiswood is a Legal Adviser at the UK Government Legal Department. She has advised the UK Department for International Trade on investment treaty negotiations and disputes, trade law and international law issues. Prior to this, Sarah was a lawyer at the Australian Attorney-General's Department, where she advised the Australian Government on investment treaty disputes, 
international law, constitutional law and public law. She has also worked as a judicial clerk at the High Court of Australia (Australia's final court of appeal) and at the Hong Kong International Arbitration Centre. Sarah holds a Masters of Law (International Law) from the University of Cambridge.

Open Access This chapter is licensed under the terms of the Creative Commons Attribution 4.0 International License (http://creativecommons.org/licenses/by/4.0/), which permits use, sharing, adaptation, distribution and reproduction in any medium or format, as long as you give appropriate credit to the original author(s) and the source, provide a link to the Creative Commons license and indicate if changes were made.

The images or other third party material in this chapter are included in the chapter's Creative Commons license, unless indicated otherwise in a credit line to the material. If material is not included in the chapter's Creative Commons license and your intended use is not permitted by statutory regulation or exceeds the permitted use, you will need to obtain permission directly from the copyright holder. 